\title{
Literatura y Revolución en las Letras Cubanas
}

\section{INTRODUCCION .}

En los últimos quince años, y por razones harto conocidas, la literatura cubana se ha convertido en una de las más influyentes de América Latina. La política cultural de la Revolución triunfante y el eco extraordinario que esa política ha tenido en toda América, ha permitido a las letras cubanas determinar en gran medida el curso de la nueva literatura. Sin embargo, y a pesar de que se ha escrito mucho sobre este período y en particular sobre la nueva literatura producida en Cuba, poco de lo escrito alcanza un nivel de investigación y crítica que lo justifique.

Para subsanar en modesta parte la carencia de esa critica, el Antilles Research Program, de la Universidad de Yale, ha auspiciado en los últimos cinco años, sendos simposios sobre letras cubanas. El primero, realizado en 1970 bajo la dirección del Profesor José Juan Arrom, de dicha Universidad, estuvo dedicado a una revaloración de José Martí. El segundo, que tuvo lugar en 1971 y estuvo a cargo del Profesor Klaus Muiller-Bergh (entonces en Yale), fue dedicado a Alejo Carpentier. ${ }^{1}$ Los tres siguientes (1973-1974)han sido organizados bajo mi dirección y han estado dedicados respectivamente a José Lezama Lima, los nuevos novelistas cubanos y la crítica literaria en las letras cubanas contemporáneas.

Al recoger hoy en este número especial de la REVISTA IBEROAMERICANA la mayoría de los trabajos presentados en los tres últimos simposios, he tratado de ampliar el ámbito de resonancia de los mismos. ${ }^{2}$ También obedece al mismo propósito la in-

\footnotetext{
${ }^{1}$ Los trabajos leídos en este simposio se recogieron en Asedios a Carpentier, selección y nota preliminar de Klaus Müller-Bergh (Santiago de Chile, Editorial Universitaria, 1972).

${ }^{2}$. En el simposio dedicado a Lezama Lima (abril 14, 1973) se leyeron los trabajos de Severo Sarduy, José Juan Arrom, Roberto González Echevarría, Guillermo Sucre, Julio Ortega y Emir Rodriguez Monegal que se recogen en la segunda sección de este número especial. En el simposio dedicado a la "Nueva Novela cubana" (abril 6, $1974^{\circ}$ se leyeron los trabajos de Alfred MacAdam, Suzanne Jill Levine, Emir Rodríguez Monegal y Eduardo González que se incorporan ahora a la tercera sección. En el simposio sobre "La crítica literaria en las letras cubanas contemporáneas' 'idiciembre 7,1974 )' se leyeron los trabajos de Enrico Mario Santi (que aparece en la sección segunda), John Deredita (sección tercera) y Alexander Coleman y Emir Rodríguez Monegal (ambos en la sección cuarta).
} 
corporación de trabajos sobre temas afines que he sumado al volumen. ${ }^{3}$ De esta manera, el lector especializado tendrá en sus manos un conjunto de estudios que, a pesar de la diversidad de orígenes, están signados por la misma preocupación: leer el texto de la nueva literatura cubana desde un punto de vista crítico.

No habría podido realizar la tarea de investigación y análisis que presupone esta colección sin el generoso apoyo del director del Antilles Research Program, Profesor Sydney Mintz, ni del Latin American Studies Council, de la Universidad de Yale. Tampoco la publicación de este volumen habría podido ser posible sin la colaboración del Sr. Joseph Goldsen, del Concilium for International and Area Studies, de la misma Universidad, y del Profesor Alfredo A. Roggiano, de la Universidad de Pittsburgh, y director de la REVISTA IBEROAMERICANA. Una deuda de permanente consulta y fructífero intercambio tengo asimismo con el Profesor Roberto González Echevarría, de la Universidad de Cornell, que me ayudó a planear y ejecutar los simposios que dieron origen a este volumen, y luego continuó su colaboración sugiriéndome trabajos que pudieran completarlo. A todos ellos, y en particular a los colaboradores de este número especial, mi más profundo agradecimiento.

Yale University

EMIR RODRIGUEZ MONEGAL

3 Los trabajos de Modes to G. Sánchez y Eduardo G. González que aparecen en la primera sección pertenecen a sendos estudios críticos sobre Carpentier que están preparando estos investigadores. El trabajo de Justo C. Ulloa y Leonor A. de Ulloa sobre Sarduy (sección tercera) fue enviado especialmente para la REVISTA IBEROAMERICANA, así como el estudio de Alicia Borinsky sobre Reinaldo Arenas (sección tercera) y las Reseñas que aparecen en la sección quinta y están firmadas por José Miguel Oviedo, Carlos J. Cano y Roberto González Echevarría. 